\title{
Tobacco cessation: attitude and practice of dentists in Northern United Arab Emirates
}

Danavanthi Bangera' ${ }^{1}$ Mohamed Takana² and Jayakumary Muttappallymyalil ${ }^{3}$

${ }^{1}$ Gulf Medical Hospital \& Research Centre, Ajman, United Arab Emirates (Correspondence to: D.S. Bangera: dhansbang@gmail.com). ${ }^{2}$ Al Madina Primary Health Care Centre, Ajman, United Arab Emirates. ${ }^{3}$ Department of Community Medicine, Gulf Medical University, Ajman, United Arab Emirates.

\begin{abstract}
Background: Tobacco use has profound health consequences globally. Dentists with positive attitudes towards tobacco cessation counselling show minimal involvement in practice.

Aims: To assess the attitude and practice of dentists in the Northern United Arab Emirates towards tobacco cessation advice.

Methods: An interviewer-administered, questionnaire-based study was conducted among 250 dentists practicing in the Northern Emirates in 2015. Statistical analysis was performed with the $\chi^{2}$ test and multivariate analysis.

Results: Around $88 \%$ of dentists exhibited good attitudes but only $37 \%$ had good practice of providing tobacco cessation advice to their patients. Nationality, level of education, total duration of practice and personal use of tobacco were significantly associated with attitude towards tobacco cessation. Nonusers of tobacco showed an odds ratio of 3.12 ( $95 \%$ confidence interval: 1.18-8.20) towards good attitude.

Conclusions: Most of the surveyed dentists had a good attitude towards provision of tobacco cessation advice, but comparatively suboptimal practice was observed. We recommend providing training to the dentists on the methods and techniques of tobacco cessation.

Keywords: Dentists, smoking, tobacco, cessation, United Arab Emirates,

Citation: Bangera D; Takana M; Muttappallymyalil J. Tobacco cessation: attitude and practice of dentists in Northern United Arab Emirates. East Mediterr Health J. 2018;24(5):419-426. https://doi.org/10.26719/2018.24.5.419

Received: 16/07/16; accepted: 01/03/17

Copyright (C) World Health Organization (WHO) 2018. Some rights reserved. This work is available under the CC BY-NC-SA 3.0 IGO license (https:// creativecommons.org/licenses/by-nc-sa/3.o/igo).
\end{abstract}

\section{Introduction}

Globally, tobacco use has profound health consequences not only for the smokers but also for those who are exposed to second- and thirdhand smoking (1). There are different forms of tobacco available and consumed worldwide but cigarettes are predominant and account for $96 \%$ of global sales $(1,2)$. In the Middle East, cigarette smoking has emerged as a serious public health problem (3).

Tobacco smoke and smokeless tobacco cause a variety of oral mucosal changes due to the irritants and toxins present in tobacco. In an effort to reduce mortality and morbidity associated with tobacco use, African and Middle Eastern countries have developed guidelines on the utilization of appropriate tobacco control policies initiated by the World Health Organization (WHO) Framework Convention on Tobacco Control (FCTC) $(4,5)$. This policy also includes strategies such as the 5As (Ask, Advise, Assess, Assist and Arrange) and the ABC algorithm Ask about the smoking status, provide Brief advice to stop smoking to all smokers, and assist in Cessation those who are willing to quit (4-6).

Generally, dentists have a favourable and encouraging attitude towards smoking cessation counselling. Most dentists believe it to be their responsibility to help their patients with tobacco cessation or to prevent tobacco use. A study in India showed that $98.7 \%$ of dentists felt that they were responsible for providing tobacco cessation advice, and $94.7 \%$ reported that they were confident in providing tobacco cessation advice to their patients (7-12). A study among dentists in Kelantan, Malaysia showed that $72.7 \%$ were confident in giving such counselling. However, only $4.8 \%$ of the dentists viewed that their advice would be effective and only $2.4 \%$ were positive about their patients' ability to stop tobacco use (13). Attitude of dentists in providing tobacco use cessation advice also depends on many background factors such as past experiences with counselling, and interest and rewards in practice and training (13,14). In a study among Hong Kong dentists, $89 \%$ strongly agreed that dentists play an important role in delivering tobacco cessation advice (15). Likewise, 80.6\% of dentists in Saudi Arabia agreed about the importance of providing tobacco cessation counselling and only $9 \%$ of them disagreed (16).

Despite this encouraging and favourable attitude, involvement of dentists in tobacco cessation advice has been minimal. In India, $45 \%$ of dentists did not provide tobacco cessation pamphlets, although $81.5 \%$ did have posters about this in the waiting room (7). In Malaysia, although $82.1 \%$ dentists offered tobacco cessation advice to their patients, only $17.9 \%$ were really involved in cessation advice; $20.2 \%$ provided an explanation on the health implications of tobacco use; and $21.4 \%$ offered motivation to their patients in relation to tobacco cessation (13). 
A study in Hong Kong showed that dentists practicing in government sectors and those who have undergone training in tobacco cessation were more likely to enquire about their patients' smoking status. Thus, appropriately trained dentists were 14 times more familiar with contacting local smoking cessation agencies and 8 times more likely to provide advice for smoking cessation to their patients (15). This study reflected the need for both didactic and clinical training in counselling skills in the undergraduate curriculum. Moreover, dentists should also undergo ongoing tobacco cessation training that will help them to acquire better knowledge and updated techniques (15).

Dentists are healthcare providers and play a vital role in educating the community about the effects of tobacco use on oral health and general health (17-19). Engagement of dentists in smoking cessation programmes will allow them to become involved in this significant area of prevention. The present study was conducted to assess the attitude and practice of dentists in the Northern United Arab Emirates towards providing tobacco cessation advice to their patients. We also assessed the association between attitude and practice in providing tobacco cessation advice and sociodemographic characteristics, years of practice, areas of specialization and tobacco use of dentists.

\section{Methods}

In 2015, we used a cross-sectional study to assess the attitude and practice of dentists in the Northern Emirates towards giving tobacco cessation advice to their patients. The study population included dentists practicing in hospitals, dental clinics, polyclinics, dental clinics in medical centres, and dental centres in primary healthcare centres in the Northern Emirates. We included general dental practitioners and specialists in dentistry. Dentists who were not willing to participate and those who were exclusively academics were excluded.

A minimum sample size of 245 was calculated based on the formula for cross-sectional studies. The sampling frame was obtained from the lists of Marketing Division, Gulf Medical College Hospital and Research Centre, and Health Communication Division, Gulf Medical University, Ajman.

An interviewer-administered questionnaire was content and face validated by 3 experts from the field of tobacco research and 2 from the field of dentistry. Twentytwo questions were included each on attitude and practice towards giving smoking cessation advice. The questions were revised based on suggestions received from the experts. Pilot testing of the questions was carried out among 5 dentists to assess the comprehensiveness, feasibility and time needed to complete the questionnaire.

Ethical approval was obtained from Ethics and Research Committee of Gulf Medical University, Ajman and the Ethics Committee of the Ministry of Health, United Arab Emirates. Participants were approached personally and the purpose of the study was explained to them. Written consent was obtained prior to administration of the questionnaire and participants were recruited conveniently till the required sample size was achieved. A total of 250 dentists participated in the study with a response rate of $89.3 \%$.

The data were fed into an Excel spreadsheet and analysed using SPSS version 22 software. Results are presented as frequencies and percentages. Attitude of the dentists towards tobacco cessation advice was assessed by grading on a 0-4 Likert scale that was rated as strongly disagree, disagree, neutral, agree and strongly agree. Each statement was assessed as good attitude if the score was $>2$ and poor attitude if the score was $\leq 2$. Tobacco cessation advice in practice was assessed by grading on a 0-2 Likert scale that was rated as never, occasionally and always. Each statement was assessed as good practice if the score was $>1$ and poor practice if the score was $\leq 1$. The $\chi^{2}$ test was used to assess the association between dependent and independent variables. The variables with a level of significance of $\mathrm{P} \leq 0.1$ were included in the 2nd level of simple binary logistic regression. The variables showing a significant level were included in a multiple binary logistic regression model to estimate the net effect of each variable on tobacco cessation practice. The variables that gave adjusted odds ratio with a level of significance of $\mathrm{P} \leq 0.05$ were concluded to be factors that influenced tobacco cessation advice.

\section{Results}

Table 1 illustrates the association between participants' sociodemographic characteristics and their attitude towards tobacco cessation intervention. We found that female participants, those $<40$ years of age and those with postgraduate and higher education had higher scores for good attitude compared to male participants, those aged $\geq 40$ years of age and those with graduate education. None of these differences was significant. In contrast, participants from other regions had a significantly higher score for good attitude compared to those from the World Health Organization Eastern Mediterranean Region.

Table 2 shows the association between details of clinical practice and the participants' total attitude score towards tobacco cessation advice. Specialists, participants practicing in government settings, those who consulted $<60$ patients per week and those who attended training programmes had higher good attitude scores for all the domains (Ask, Advise, Assess, Assist and Arrange) as compared to general practitioners, those practicing in private setting, those who consulted $\geq 60$ patients per week and those who had not attended any training programme. None of these differences was significant. Good attitude was significantly higher among the participants with $\leq 10$ years of clinical practice as compared to those with $>10$ years of clinical practice.

Around $22(71.0 \%)$ current tobacco users had a good attitude (score $>44$ ) and only $9(29.0 \%)$ had a poor attitude (score $\leq 44)$ towards all the domains. Among the nontobacco users, 199 (90.9\%) had a good attitude (score > 


\begin{tabular}{|c|c|c|c|c|c|c|}
\hline \multirow{3}{*}{$\begin{array}{l}\text { Sociodemographic } \\
\text { characteristics }\end{array}$} & \multirow[t]{3}{*}{ Groups } & \multicolumn{4}{|c|}{ Total attitude score } & \multirow[t]{3}{*}{$\mathbf{P}$} \\
\hline & & \multicolumn{2}{|c|}{ Good (score > 44) } & \multicolumn{2}{|c|}{ Poor (score $\leq 44)$} & \\
\hline & & No. & $\%$ & No. & $\%$ & \\
\hline \multirow[t]{2}{*}{ Age groups (yr) } & $<40$ & 135 & 90.0 & 15 & 10.0 & \multirow{2}{*}{0.33} \\
\hline & $\geq 40$ & 86 & 86.0 & 14 & 14.0 & \\
\hline \multirow[t]{2}{*}{ Gender } & Male & 94 & 87.0 & 14 & 13.0 & \multirow{2}{*}{0.56} \\
\hline & Female & 127 & 89.4 & 15 & 10.6 & \\
\hline \multirow[t]{2}{*}{ Nationality } & EMR & 94 & 83.2 & 19 & 16.8 & \multirow{2}{*}{$\leq 0.05$} \\
\hline & Other Regions & 127 & 92.7 & 10 & $7 \cdot 3$ & \\
\hline \multirow[t]{2}{*}{ Education } & Graduate & 132 & 85.7 & 22 & 14.3 & \multirow{2}{*}{0.09} \\
\hline & Postgraduate and higher & 89 & 92.7 & 7 & 7.3 & \\
\hline
\end{tabular}

$\overline{E M R}=$ World Health Organization Eastern Mediterranean Region.

\begin{tabular}{|c|c|c|c|c|c|c|}
\hline \multirow[t]{3}{*}{ Details of clinical practice } & \multirow[t]{3}{*}{ Groups } & \multicolumn{4}{|c|}{ Total attitude score } & \multirow[t]{3}{*}{$\boldsymbol{P}$} \\
\hline & & \multicolumn{2}{|c|}{ Good (score $>44)$} & \multicolumn{2}{|c|}{ Poor (score $\leq 44)$} & \\
\hline & & No. & $\%$ & No. & $\%$ & \\
\hline \multirow[t]{2}{*}{ Type of practice } & General & 137 & 86.2 & 22 & 13.8 & \multirow{2}{*}{0.14} \\
\hline & Specialist & 84 & 92.3 & 7 & 7.7 & \\
\hline \multirow[t]{2}{*}{ Total duration of practice } & $\leq 10$ years & 92 & 93.9 & 6 & 6.1 & \multirow{2}{*}{$\leq 0.05$} \\
\hline & $>10$ years & 129 & 84.9 & 23 & 15.1 & \\
\hline \multirow[t]{2}{*}{ Type of settings } & Government & 47 & 90.4 & 5 & 9.6 & \multirow{2}{*}{0.62} \\
\hline & Private & 174 & 87.9 & 24 & 12.1 & \\
\hline \multirow[t]{2}{*}{ No. of patients seen/wk } & $<60$ & 152 & 88.9 & 19 & 11.1 & \multirow{2}{*}{0.72} \\
\hline & $\geq 60$ & 69 & 87.3 & 10 & 12.7 & \\
\hline \multirow[t]{2}{*}{ Training programme attended } & Yes & 22 & 95.7 & 1 & 4.3 & \multirow[t]{2}{*}{$0.49^{\mathrm{a}}$} \\
\hline & No & 199 & 87.7 & 28 & 12.3 & \\
\hline
\end{tabular}

aby Fisher's exact test.

44) and 20 (9.1\%) had a poor attitude (score $\leq 44)$ towards all the domains. Good attitude was significantly higher among non-tobacco users compared to current tobacco users $(\mathrm{P} \leq 0.01)$

Table 3 shows the predictors of good attitude towards tobacco cessation advice. The $\chi^{2}$ test showed that nationality, level of education, total duration of practice and personal use of tobacco were significantly associated with attitude towards tobacco cessation at $\mathrm{P}$ $\leq$ 0.1. After adjustment of the confounding factors, these factors were subjected to multiple logistic regression. Participants from other regions were 2.38 times more likely to have a good attitude towards tobacco cessation advice as compared to those from the Eastern Mediterranean Region. Participants with postgraduate and higher education were 2.79 times more likely to have a good attitude towards tobacco cessation advice than those with graduate education were. Participants with $\leq$ 10 years of clinical practice were 3.61 times more likely to have a good attitude towards tobacco cessation advice as compared to those with $>10$ years clinical practice.
Nonusers of tobacco were 3.12 times more likely to have a good attitude towards tobacco cessation advice as compared to tobacco users.

Table 4 shows the association between sociodemographic characteristics and participants' total practice score for all domains toward tobacco cessation advice. Female dentists, those aged $\geq 40$ years, those with graduate education, and those from other regions had higher good practice scores for all the domains as compared to male participants, those aged $<40$ years, those with postgraduate and higher education, and those from the Eastern Mediterranean Region. None of these differences was significant.

Table 5 shows the association between the dentists' details of clinical practice and the total practice score towards tobacco cessation advice. Good practice scores for all domains were higher for general practitioners, dentists with $>10$ years clinical practice, those seeing $\geq$ 60 patients per week, those practicing in private settings, and those who attended a training programme compared to specialists, dentists with $\leq 10$ years clinical practice, 


\begin{tabular}{|c|c|c|c|c|}
\hline \multirow[t]{3}{*}{ Factors } & \multicolumn{4}{|c|}{ Good attitude } \\
\hline & \multicolumn{2}{|c|}{ Crude } & \multicolumn{2}{|c|}{ Adjusted } \\
\hline & OR & $95 \% \mathrm{CI}$ & OR & $95 \% \mathrm{CI}$ \\
\hline \multicolumn{5}{|l|}{ Nationality } \\
\hline Other Regions & $2.57(\leq 0.05)$ & $1.14-5.78$ & $2.38(\leq 0.05)$ & $1.01-5.62$ \\
\hline EMR (Ref) & 1 & - & 1 & - \\
\hline \multicolumn{5}{|l|}{ Education } \\
\hline Postgraduates and higher & $2.12(\leq 0.1)$ & $0.87-5.17$ & $2.79(\leq 0.05)$ & $1.07-7.23$ \\
\hline Graduates (Ref) & 1 & - & 1 & - \\
\hline \multicolumn{5}{|l|}{ Total duration of practice } \\
\hline$\leq 10$ years & $2.73(\leq 0.05)$ & $1.07-6.98$ & $3.61(\leq 0.05)$ & $1.33-9.76$ \\
\hline$>10$ years (Ref) & 1 & - & 1 & - \\
\hline \multicolumn{5}{|l|}{ Personal use of tobacco } \\
\hline No & $4.07(\leq 0.01)$ & $1.65-10.03$ & $3.12(\leq 0.05)$ & $1.18-8.20$ \\
\hline Yes (Ref) & 1 & - & 1 & - \\
\hline
\end{tabular}

EMR $=$ World Health Organization Eastern Mediterranean Region .

\begin{tabular}{|c|c|c|c|c|c|c|}
\hline \multirow{3}{*}{$\begin{array}{l}\text { Sociodemographic } \\
\text { characteristics }\end{array}$} & \multirow[t]{3}{*}{ Groups } & \multicolumn{4}{|c|}{ Total practice score } & \multirow[t]{3}{*}{$\mathbf{P}$} \\
\hline & & \multicolumn{2}{|c|}{ Good (score > 22) } & \multicolumn{2}{|c|}{ Poor $($ score $\leq 22)$} & \\
\hline & & No. & $\%$ & No. & $\%$ & \\
\hline \multirow[t]{2}{*}{ Age groups (yr) } & $<40$ & 53 & 35.3 & 97 & 64.7 & \multirow{2}{*}{0.46} \\
\hline & $\geq 40$ & 40 & 40.0 & 60 & 60.0 & \\
\hline \multirow[t]{2}{*}{ Gender } & Male & 38 & 35.2 & 70 & 64.8 & \multirow{2}{*}{0.57} \\
\hline & Female & 55 & 38.7 & 87 & 61.3 & \\
\hline \multirow[t]{2}{*}{ Nationality } & EMR & 39 & 34.5 & 74 & 65.5 & \multirow{2}{*}{0.4} \\
\hline & Other Regions & 54 & 39.4 & 83 & 60.6 & \\
\hline \multirow[t]{2}{*}{ Education } & Graduate & 59 & 38.3 & 95 & 61.7 & \multirow{2}{*}{0.65} \\
\hline & Postgraduate and higher & 34 & 35.4 & 62 & 64.6 & \\
\hline
\end{tabular}

$E M R=$ World Health Organization Eastern Mediterranean Region .

those seeing $<60$ patients per week, those practicing in government settings, and those who did not attend any training programme. None of these differences was significant.

Among current tobacco users, 23 (74.2\%) had poor practice (score $\leq 22)$ and only $8(25.8 \%)$ had good practice (score $>22$ ) towards all the domains. Among the nonusers of tobacco, $134(61.2 \%)$ had poor practice (score $\leq 22)$ and $85(38.8 \%)$ had good practice (score $>22$ ) towards all the domains. None of these differences was significant.

Among all the variables, good attitude of the dentists was significantly associated with good practice towards tobacco cessation advice $(\mathrm{P} \leq 0.05)$. When this factor was included in the simple binary logistic regression model, dentists with a good attitude were 3.18 times (95\% confidence interval: 1.17-8.64) more likely to have good practice towards tobacco cessation advice as compared to those with poor attitude.

\section{Discussion}

The current tobacco epidemic is one of the greatest threats to global health. Tobacco use has a detrimental impact on oral as well as general health $(16,20)$. It is imperative that dentists recognize the need to include intervention for tobacco use prevention and cessation along with dental treatment. Our study aimed to determine the attitude and practice regarding tobacco cessation intervention among dentists practicing in the Northern United Arab Emirates.

Most dentists had a good attitude towards the domains Ask (81.2\%), Advise (89.6\%), Assess (66.8\%), Assist (79.2\%) and Arrange (69.2\%). Studies in Malaysia, India, Hong Kong, Saudi Arabia and Islamic Republic of Iran reported that most dentists had an encouraging attitude towards providing tobacco cessation advice to their patients $(7,8$, $13,15,16,21)$. In contrast, a similar study conducted in the United States of America (USA) reported that only 58\% 


\begin{tabular}{|c|c|c|c|c|c|c|}
\hline \multirow[t]{3}{*}{ Details of clinical practice } & \multirow[t]{3}{*}{ Groups } & \multicolumn{4}{|c|}{ Total practice score } & \multirow[t]{3}{*}{$\mathbf{P}$} \\
\hline & & \multicolumn{2}{|c|}{ Good (score > 22) } & \multicolumn{2}{|c|}{ Poor $($ score $\leq 22)$} & \\
\hline & & No. & $\%$ & No. & $\%$ & \\
\hline \multirow[t]{2}{*}{ Type of practice } & General & 61 & 38.4 & 98 & 61.6 & \multirow{2}{*}{0.6} \\
\hline & Specialist & 32 & 35.2 & 59 & 64.8 & \\
\hline \multirow[t]{2}{*}{ Total duration of practice } & $\leq 10$ years & 36 & 36.7 & 62 & 63.3 & \multirow{2}{*}{0.90} \\
\hline & $>10$ years & 57 & 37.5 & 95 & 62.5 & \\
\hline \multirow[t]{2}{*}{ No. of patients seen/wk } & $<60$ & 62 & 36.3 & 109 & 63.7 & \multirow{2}{*}{0.65} \\
\hline & $\geq 60$ & 31 & 39.2 & 48 & 60.8 & \\
\hline \multirow[t]{2}{*}{ Type of settings } & Government & 15 & 28.8 & 37 & 71.2 & \multirow{2}{*}{0.16} \\
\hline & Private & 78 & 39.4 & 120 & 60.6 & \\
\hline \multirow[t]{2}{*}{ Training programme attended } & Yes & 11 & 47.8 & 12 & 52.2 & \multirow{2}{*}{0.27} \\
\hline & No & 82 & 36.1 & 145 & 63.9 & \\
\hline
\end{tabular}

of dentists had a positive attitude (22). Attitude depends on many factors such as knowledge and interest in practicing tobacco cessation intervention, which were not explored in this study. However, this varying attitude may be attributable to differences in interest in and knowledge of the perceived duties of dentists among the dental community.

Total attitude score of female dentists and dentists aged $<40$ years was higher than in other groups but was not significantly associated. This observation was in conformity with that of Binnal et al., who reported that younger dentists had a better attitude towards tobacco cessation interventions than their older counterparts (23). One possible reason is that younger dentists are perceived to have more interest in such intervention compared to older dentists. Dentists who had attended intervention training had a better attitude than those who had not but the difference was not significant. This finding is in accordance with a study in the USA that reported that dentists who received training had a significantly more positive attitude towards tobacco cessation counselling (14). This indicates that training in tobacco cessation programmes has the potential to increase awareness among dentists and make them more involved in the provision of tobacco cessation counselling to their patients. Dentists who have never consumed tobacco had a significantly higher good attitude score than those that had ever been tobacco users. This finding is consistent with studies in Kuwait, Kenya and Finland that reported a negative attitude towards patient counselling about smoking among healthcare professionals who smoke compared to those who are nonsmokers (24-26). This provides insight into the fact that dentists hold strong beliefs that they serve as a role model to their patients $(11,12)$.

In the present survey, actual involvement of the dentists in tobacco cessation interventions were reported as follows: Ask (39.6\%), Advise (68.4\%), Assess (24\%), Assist (19.2\%) and Arrange (18.8\%). This is consistent with previous studies (22,27-30). Assisting, assessing and arranging were the least-often-delivered services by dentists despite an encouraging attitude towards them. This indicates dentists' perceived lack of skill for their actual involvement in tobacco cessation interventions.

Good practice towards all the domains was observed to be higher among female dentists, dentists aged $\geq 40$ years and general practitioners as compared to their counterparts but this association was not significant. Also, no significant association of total practice was observed with regard to nationality, duration of practice and number of patients treated per week. Dentists who attended an intervention training programme had better good practice than those who had not but this difference was not significant. This finding is in line with a study done in Hong Kong that stated that government dentists and those who received training were significantly more likely to have good practice towards tobacco cessation than their counterparts (15). Similar findings have been reported in the USA and Ontario, Canada $(14,31)$. A Cochrane review concluded that healthcare professionals who were trained were better in offering tobacco cessation interventions (32). Good practice was observed more among nonusers of tobacco as compared to current tobacco users but the difference was not significant. This is in accordance with other studies $(24,33,34)$. By comparison, a study in Ontario showed that former smokers and never smokers were significantly more likely to have good practice than current smokers have (31). This indicates increased awareness among nonsmokers about the adverse effects of tobacco use on oral as well as general health. Thus, effectiveness of any intervention may increase if the counselling is done by dentists who do not consume tobacco.

Dentists with a good attitude towards the domains Ask, Advise, Assess, Assist and Arrange were significantly more likely to have good practice in all the domains towards the provision of tobacco cessation interventions. This was similar to previous studies $(22,25,35,36)$. This indicates that efforts to improve the attitude of dentists towards tobacco cessation interventions would increase the actual involvement of the dentists in provision of such interventions to their patients. 
This study had some limitations. The cross-sectional design of the study allowed us only to provide a snapshot of the situation. However, the study assessed the attitude and practice of the dentists towards tobacco cessation advice, which were less likely to change over time. Dentists were recruited by convenience sampling, which may have contributed to selection bias. This limits the generalization of the results as the sample may not have been truly representative of the wider population. However, participants were recruited from a large geographical area and most dentists were able to respond to the survey.

\section{Conclusion}

The majority of the surveyed dentists had a good attitude towards provision of tobacco cessation services. However, despite this encouraging attitude, few dentists provided tobacco cessation intervention to their patients. Factors that were significantly associated with a good at-

Funding: None.

Competing interests: None declared. titude towards tobacco cessation advice were nationality, level of education, total duration of practice and tobacco consumption of the dentists. Good attitude of the dentists towards tobacco cessation advice was significantly associated with good practice of the dentists in provision of advice.

\section{Recommendations}

We recommend training dentists at the individual and community level on the methods and techniques of tobacco cessation strategies. Training programmes should be planned and implemented by healthcare management teams and concerned authorities for all dental professionals at regular intervals. Skill-based approaches may be required to enhance the confidence and competence of the dentists in offering tobacco cessation intervention. Moreover, it would be advisable to arrange cessation intervention for healthcare workers, including dentists, as they are role models, especially to adolescents.

\section{Sevrage tabagique : attitude et pratique des dentistes au nord des Émirats arabes unis Résumé}

Contexte : Le tabagisme a de profondes répercussions sur la santé au niveau mondial. Les dentistes qui ont une attitude favorable au regard du conseil en matière de sevrage tabagique se montrent peu impliqués dans la pratique.

Objectif : Évaluer l'attitude et la pratique des dentistes du nord des Émirats arabes unis au regard de la dispensation de conseils en vue du sevrage tabagique.

Méthodes : Une étude basée sur un questionnaire et administrée par un enquêteur a été menée en 2015 auprès de 250 dentistes exerçant dans le nord des Émirats. Des analyses statistiques ont été effectuées à l'aide du test du $\chi^{2}$ et de l'analyse multivariée.

Résultats : Environ $88 \%$ des dentistes affichaient une attitude positive mais seuls $37 \%$ faisaient preuve d'une bonne pratique de dispensation de conseils en faveur du sevrage tabagique auprès de leurs patients. La nationalité, le niveau d'éducation, la durée totale de l'exercice et le tabagisme personnel étaient associés de façon significative à l'attitude adoptée face au sevrage tabagique. Chez les non-fumeurs, l'odds ratio pour l'attitude favorable était de 3,12 (IC à 95 \% : 1,18$8,20)$.

Conclusion : La plupart des dentistes interrogés affichaient une attitude positive quant à la dispensation de conseils en matière de sevrage tabagique, alors que la pratique observée était comparativement insuffisante. Nous recommandons de proposer une formation aux dentistes au regard des méthodes et techniques du sevrage tabagique. 


$$
\begin{aligned}
& \text { الإقلاع عن استهالك التبغ: التجاهات وممارسات أطباء الأسنان في الإمارات الشمالية من دولة الإمار ات العربية المتحدة } \\
& \text { دانافانتي بانجيرا، محمد تاكانا، جاكوماري موتابلي ميالل }
\end{aligned}
$$

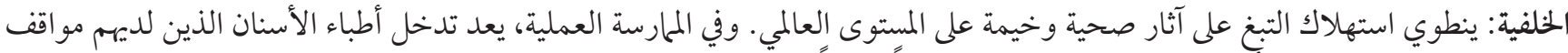

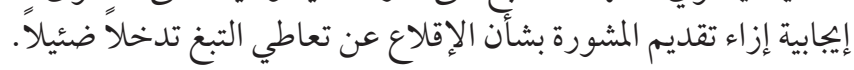

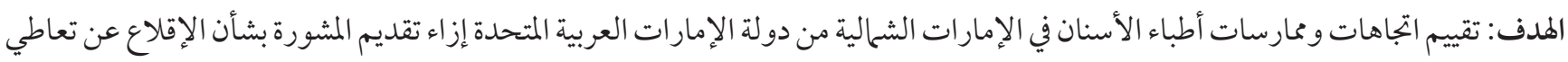

$$
\begin{aligned}
& \text { التبغ. }
\end{aligned}
$$

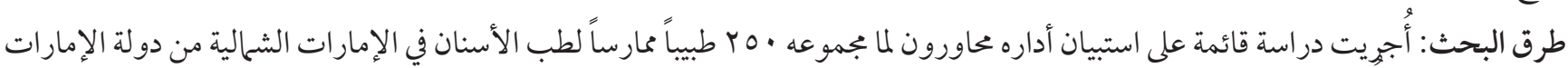

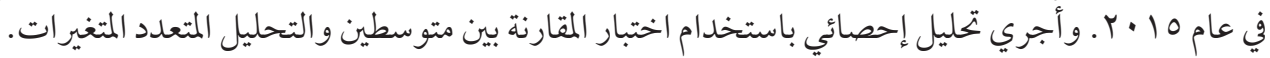

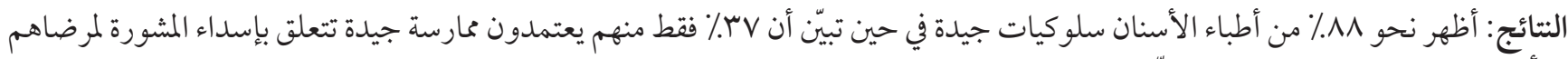

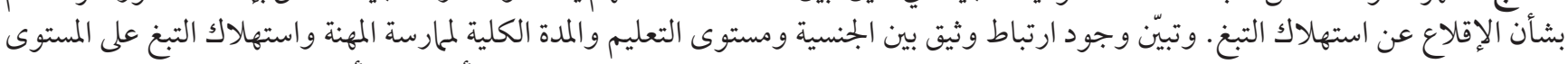

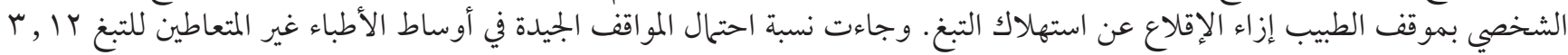

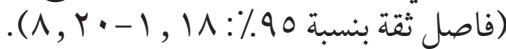

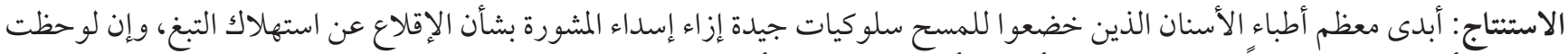

$$
\begin{aligned}
& \text { ممارسات أقل من المتظظر نسبياً. ونوصي بتدريب أطباء الأسنان على طرق وأساليب الإقلاع عن استهلاك التبغ. }
\end{aligned}
$$

\section{References}

1. Eriksen M, Mackay J, Ross H. The tobacco atlas. 4th edition. American Cancer Society, World Lung Foundation; 2012.

2. Centers for Disease Control and Prevention. Health effects of cigarette smoking. https://www.cdc.gov/tobacco/data_statistics/ fact_sheets/health_effects/effects_cig_smoking/index.htm, accessed18 December 2017).

3. Global Youth Tobacco Survey United Arab Emirates (UAE) (ages 13-15) fact sheet. World Health Organization Eastern Mediterranean Region; 2010 (http://www.emro.who.int/images/stories/tfi/documents/GYTS_FS_UAE_R2.pdf?ua=1, accessed 18 December 2017).

4. Ali AY, Safwat T, Onyemelukwe G, Otaibi MA, Amir AA, Nawas YN, et al. Smoking prevention and cessation in the Africa and Middle East region: a consensus draft guideline for healthcare providers - executive summary. Respiration. 2012;83(5):423-32. http://dx.doi.org/10.1159/000337726 PMID:22487605

5. Toolkit for delivering the 5A's and 5R's brief tobacco interventions to TB patients in primary care. Geneva: World Health Organization; 2014. (http://apps.who.int/iris/bitstream/10665/112836/1/9789241506946_eng.pdf?ua=1, accessed 18 December 2017).

6. New Zealand smoking cessation guidelines. Wellington: Ministry of Health; 2007 (http://www.treatobacco.net/en/uploads/ documents/Treatment\%20Guidelines/New\%20Zealand\%20treatment\%20guidelines\%20in\%20English\%202007.pdf, accessed 18 December 2017).

7. Bhat N, Jyothirmai-Reddy J, Gohil M, Khatri M, Ladha M, Sharma M. Attitudes, practices and perceived barriers in smoking cessation among dentists of Udaipur City, Rajasthan, India. Addict Health. 2014 Winter;6(1-2):73-80. PMID:25140220

8. Amit S, Bhambal A, Saxena V, Basha S, Saxena S, Vanka A. Tobacco cessation and counseling: a dentists' perspective in Bhopal city, Madhya Pradesh. Indian J Dent Res. 2011 May-Jun;22(3):400-3. http://dx.doi.org/10.4103/0970-9290.87061 PMID:22048579

9. Saddichha S, Rekha DP, Patil BK, Murthy P, Benegal V, Isaac MK. Knowledge, attitude and practices of Indian dental surgeons towards tobacco control: advances towards prevention. Asian Pac J Cancer Prev. 2010;11(4):939-42. PMID:21133605

10. Parakh A, Megalamanegowdru J, Agrawal R, Hathiwala S, Chandrakar M, Tiwari R, et al. Dental practitioners self reported performance of tobacco cessation counseling interventions: a cross sectional study. Asian Pac J Cancer Prev. 2013;14(10):6141-5. http://dx.doi.org/10.7314/APJCP.2013.14.10.6141 PMID:24289640

11. Mitra D, Pawar S, Mandal A, Shah RA, Rodrigues SV, Desai AB et al. Attitudes of dental professionals toward tobacco use. J Indian Soc Periodontol. 2015 May-Jun;19(3):317-21. http://dx.doi.org/10.4103/0972-124X.153488. PMID:26229275

12. Singla A, Patthi B, Singh K, Jain S, Vashishtha V, Kundu H, et al. Tobacco cessation counselling practices and attitude among the dentist and the dental auxiliaries of urban and rural areas of Modinagar, India. J Clin Diagn Res. 2014 Sep;8(9):ZC15-8. PMID:25386513

13. Ibrahim H, Norkhafizah S. Attitudes and practices in smoking cessation counselling among dentists in Kelantan. Arch Orofac Sci. 2008;3(1):11-6. http://www.dental.usm.my/aos/docs/Vol_3/Issue1/1116_fizah.pdf

14. Walsh MM, Belek M, Prakash P, Grimes B, Heckman B, Kaufman N, et al. The effect of training on the use of tobacco-use cessation guidelines in dental settings. J Am Dent Assoc. 2012 Jun;143(6):602-13. http://dx.doi.org/10.14219/jada.archive.2012.0239 PMID:22653940 
15. Li KW, Chao DV. Current practices, attitudes, and perceived barriers for treating smokers by Hong Kong dentists. Hong Kong Med J. 2014 Apr;20(2):94-101. PMID:24625385

16. Al-Moberiek A. Al-Qhatani D, Al-Otibi O, Al-Qhatni M. Dentists' Attitudes and practice towards smoking cessation and intervention in Riyadh, Saudi Arabia. J Dent. 2013;1(1):1-7. http://dx.doi.org/10.12974/2311-8695.2013.01.01.1

17. Vanka A, Roshan NM, Ravi KS, Shashikiran ND. A review of tobacco cessation services for youth in the dental clinic. J Indian Soc Pedod Prev Dent. 2009 Apr-Jun;27(2):78-84. http://dx.doi.org/10.4103/0970-4388.55326 PMID:19736499

18. Oberoi SS, Sharma G, Nagpal A, Oberoi A. Tobacco cessation in India: how can oral health professionals contribute? Asian Pac J Cancer Prev. 2014;15(5):2383-91. http://dx.doi.org/10.7314/APJCP.2014.15.5.2383 PMID:24716989

19. Mohanty VR, Rajesh GR, Aruna DS. Role of dental institutions in tobacco cessation in India: current status and future prospects. Asian Pac J Cancer Prev. 2013;14(4):2673-80. http://dx.doi.org/10.7314/APJCP.2013.14.4.2673 PMID:23725194

20. FDI World Dental Federation, World Health Organization. Tobacco or oral health: an advocacy guide for oral health professionals. Lowestoft, UK: FDI World Dental Federation; 2005 (www.who.int/oral_health/media/orh_tobacco_fdi_book.pdf?ua=1, accessed 18 December 2017).

21. Razavi SM, Zolfaghari B, Doost ME, Tahani B. Attitude and practices among dentists and senior dental students in iran toward tobacco cessation as an effort to prevent oral cancer. Asian Pac J Cancer Prev. 2015;16(1):333-8. http://dx.doi.org/10.7314/APJCP.2015.16.1.333 PMID:25640375

22. Prakash P, Belek MG, Grimes B, Silverstein S, Meckstroth R, Heckman B, et al. Dentists' attitudes, behaviors, and barriers related to tobacco-use cessation in the dental setting. J Public Health Dent. 2013 Spring;73(2):94-102. http://dx.doi.org/10.1111/j.17527325.2012.00347.x PMID:22731618

23. Binnal A, Rajesh G, Denny C, Ahmed J. Insights into the tobacco cessation scenario among dental graduates: an Indian perspective. Asian Pac J Cancer Prev. 2012;13(6):2611-7. http://dx.doi.org/10.7314/APJCP.2012.13.6.2611 PMID:22938429

24. Waheedi M, Al-Tmimy AM, Enlund H. Preparedness for the smoking cessation role among health sciences students in Kuwait. Med Princ Pract. 2011;20(3):237-43. http://dx.doi.org/10.1159/000321273 PMID:21454993

25. Watiri G. Health care providers knowledge, attitude and practice of smoking cessation interventions in public health facilities in Kiambu County, Kenya [thesis]. University of Nairobi; 2014.

26. Toriola A, Myllykangas M, Barengo N. Smoking behavior and attitudes regarding the role of physicians in tobacco control among medical students in Kuopio, Finland, in 2006. CVD Prev Control. 2008;3(2):53-60. http://dx.doi.org/10.1016/j.precon.2007.10.001

27. Uti OG, Sofola OO. Smoking cessation counseling in dentistry: attitudes of Nigerian dentists and dental students. J Dent Educ. 2011 Mar;75(3):406-12. PMID:21368264

28. Chandrashekar J, Manjunath BC, Unnikrishnan M. Addressing tobacco control in dental practice: a survey of dentists' knowledge, attitudes and behaviours in India. Oral Health Prev Dent. 2011;9(3):243-9. PMID:22068180

29. Rajasundaram P, Sequeira PS, Jain J. Perceptions of dental students in India about smoking cessation counseling. J Dent Educ. 2011 Dec;75(12):1603-10. PMID:22184600

30. Brothwell D, Gelskey S. Tobacco use cessation services provided by dentists and dental hygienists in Manitoba: part 1. Influence of practitioner demographics and psychosocial factors. J Can Dent Assoc. 2008 Dec;74(10):905. PMID:19126359

31. Babayan A, Dubray J, Haji F, Schwartz R. Provision of smoking cessation by Ontario dental health professionals. Ontario Tobacco Research Unit; 2012:1-59.

32. Ebbert J, Montori VM, Erwin PJ, Stead LF. Interventions for smokeless tobacco use cessation. Cochrane Database Syst Rev. 2011 Feb 16;(2):CDo04306. http://dx.doi.org/10.1002/14651858.CDo04306.pub4 PMID:21328266

33. Ferrante M, Saulle R, Ledda C, Pappalardo R, Fallico R, La Torre G et al. Prevalence of smoking habits, attitudes, knowledge and beliefs among health professional school students: a cross-sectional study. Ann Ist Super Sanita. 2013;49(2):143-9. http://dx.doi. org/10.4415/ANN_13_02_06 PMID:23771259

34. Asfar T, Al-Ali R, Ward KD, Vander Weg MW, Maziak W. Are primary health care providers prepared to implement an anti-smoking program in Syria? Patient Educ Couns. 2011 Nov;85(2):201-5. http://dx.doi.org/10.1016/j.pec.2010.11.011 PMID:21168300

35. Abdullah AS, Rahman AS, Suen CW, Wing LS, Ling LW, Mei LY, et al. Investigation of Hong Kong doctors' current knowledge, beliefs, attitudes, confidence and practices: implications for the treatment of tobacco dependency. J Chin Med Assoc. 2006 Oct;69(10):461-71. http://dx.doi.org/10.1016/S1726-4901(09)70310-7 PMID:17098670

36. Meredith LS, Yano EM, Hickey SC, Sherman SE. Primary care provider attitudes are associated with smoking cessation counseling and referral. Med Care. 2005 Sep;43(9):929-34. http://dx.doi.org/10.1097/01.mlr.0000173566.01877.ac PMID:16116358 